\title{
RELATIONSHIP BETWEEN HUMAN CAPITAL INVESTMENT AND EMPLOYEES' WORK EFFICIENCY IN ATAP BAUCHI: THE RELEVANCE OF TETFUND INTERVENTIONS
}

\author{
Hashim Sabo Bello ${ }^{*}$, A'isha A.G. Umar², Muhammed Kabir Ibrahim ${ }^{3}$ \\ 1,2,3Department of Business Administration and Management, School of Management Sciences, \\ Abubakar Tatari Ali Polytechnic Bauchi, Bauchi state, Nigeria \\ *Corresponding Author Email: hashimsabo@gmail.com
}

\begin{abstract}
As it is an established fact that, no nation or organization develops beyond the intellectual ability of its human resources. Nowadays, investment on human capital is paramount to sustain labour force participation in the progress and development of higher education in Nigeria. Besides, the Nigerian Universities and Colleges of Education, the polytechnic system provides another option for higher education in Nigeria where Certificates, National Diploma and Higher National Diploma courses are offered and awarded. The study aimed at evaluating the relevance of TETFund intervention on human capital investments and its bearing to employees' work efficiency in the polytechnic communities in Bauchi state to be specific and Nigeria by extension. This study generates d ata from quantitative and qualitative sources, using question naire instrument to randomly collect a cross sectional data from one of the two (2) existing polytechnics in Bauchi state of Nigeria. A total of 45 structured questionnaires were administered on our respondents and 44 were valid for analysis. The research adopted the descriptive statistics as well as the Chi-square, $\mathrm{X} 2$, to analyze the results and test the hypothesis to give the tentative prediction ab out the nature of the relationship between the research variables. Thus the research believes that there is a significant relationship between TETFund intervention in human capital investment and employees' work efficiency within educational polytechnic system in Nigeria. This research study recommended for the public organizations in Nigeria especially the education institutions to harnessed and take full advantage of the reciprocal ben efits of human capital investments and the work efficiency in edu cational tertiaryinstitutions asthis will go a long way to raise organizational achievement towards an end with the leastamount of resources.
\end{abstract}

Keywords: Human capital Investment, Relevance, Polytechnic, TETFund, Work efficiency

\begin{abstract}
Abstrak
merupakan fakta bahwa tidak ada bangsa atau organisasi yang berkembang melebihi kemampuan intelektual sumber daya manusianya. Saat ini, investasi pada sumber daya manusia sangat penting untuk mempertahankan partisipasi angkatan kerja dalam kemajuan dan perkembangan pendidikan tinggi di Nigeria. Selain itu, Universitas dan Kolese Pendidikan Nigeria, sistem politeknik memberikan pilihan lain untuk pendidikan tinggi di Nigeria di mana program Sertifikat, Diploma Nasional, dan Diploma Nasional Tinggi ditawarkan dan diberikan. Studi ini bertujuan untuk mengevaluasi relevansi intervensi TETFund pada investasi modal manusia dan hubungannya dengan efisiensi kerja karyawan di komunitas politeknik di negara bagian Bauchi secara spesifik dan Nigeria dengan perluasan. Penelitian ini menghasilkan data dari sumber kuantitatif dan kualitatif, menggunakan instrumen kuesioner untuk mengumpulkan data secara acak cross sectional dari salah satu dari dua (2) politeknik yang ada di negara bagian Bauchi Nigeria. Sebanyak 45 kuesioner terstruktur diberikan pada responden kami dan 44 valid untukanalisis. Penelitian ini menggunakan statistik deskriptif serta Chi-square, X2, untuk menganalisis hasil dan menguji hipotesis untuk memberikan prediksi tentatif tentang sifat hubungan antara variabel penelitian. Dengan demikian, penelitian percaya bahwa ada hubungan yang signifikan antara intervensi TETFund dalam investasi modal manusia dan efisiensi kerja karyawan dalam sistem politeknik pendidikan di Nigeria. Studi pen elitian ini merekomendasikan kepada organisasi publik di Nigeria terutama lembaga pendidikan untuk memanfaatkan dan memanfaatkan sepenuhnya manfaat timbal balik dari investasi modal
\end{abstract}

* Copyright (c) 2021 Hashim Sabo Bello et.al

This work is licensed under a Creative Commons Attribution-ShareAlike 4.0 International License.

Received: December 4, 2020; In Revised: January 25, 2021; Accepted: February 7, 2021 
Khazanah Sosial, Vol. 3 No. 1 : 15 - 21

Relationship between Human Capital Investment and Employees' Work Efficiency in ATAP Bauchi: The Relevance of TETFund Interventions

Hashim Sabo Bello, A’isha A.G. Umar, Muhammed Kabir Ibrahim

manusia dan efisiensi kerja di perguruan tinggi pendidikan karena ini akan sangat membantu untuk meningkatkan pencapaian organisasi menuju tujuan. dengan sumber daya paling sedikit.

Kata Kunci: Investasi Sumber Daya Manusia, Relevansi, Politeknik, TETFund, Efisiensi Kerja.

\section{INTRODUCTION}

The final cornerstone for the prosperity of nations is human resources, not money. Production factors are capital and material resources; human beings are the active agents who accumulate capital, exploit natural resources, establish social, economic and political institutions and carry out national growth (Anaduaka, 2014). On its physical and human capital stock, the economicstability and functioning of a nation depends. While the former has historically been the focus of economic study, social and behavioral science research is increasingly driven by factors that affect the improvement of human skills and talent (Adekola, 2014; Adeyemi \& Ogunsola, 2016).

People at work are of vital importance because failures are people's failures in most organizations. People are hiring, encouraging, coordinating, guiding, mobilizing and determining which product and service qualityshould begiven (Khalid \&Anuar, 2020). Human resource planning's success is paramount to the organization's survival and the challenges associated with the planning process and tremendous (Samwel, 2018). Human resources planningleads to the introduction of a new model in the organization, helps organizations assign resources, decide priority, organize power, make informed decisions and determine goals, in addition to providing the basis for other managerial tasks and being a precondition for other managerial effectiveness. Clearly, through the human resources metrics, companies are more proactive in planning the future of the organization: employee morale, applicant/acceptance ratio, development hours per employee, employee competence/flexibility steps, employee suggestions/turnover ratio. It also contributes to the comprehensive and intense production of human resources.

The search among organizations around the world to accomplish more with less is always on the rise. Again, it is very clear that organisations are committed to developing their Human Resource Management (HRM) activities, which are believed to be a sinequa non for productivity globally. Acursory look at the performance of the Tertiary Education Trust Fund (TETFund) in Nigeriain recentyears points to the reality that, although all are related, the practices of Human Resources Management (HRM) correlate significantly with employee job performance (TETFund, 2011). However, it was proposed that continuous analysis of HRM activities could be used for organisations to move over time. However, Tabiu \& Nura (2013) Despite the tremendous importance of Human Resource Management (HRM) activities in achieving employee job performance in particular and organizational performance in general, many companies do not prioritize their efficient usage in order to ensure organizational performance in developing countries such as Nigeria.

Several previous studies in this area found, the culture of human resources planning is virtually absent just as the case may be with the educational sector (i.e. ranging from the nursery, primary and secondary schools to the polytechnics and as well as the universities) (Bello et al, 2020). With the reality on ground, Asiabaka and Odionye (2011) posited that: available record shows that the number of academic staff in the Nigerian Federal Universities is far below that of non-academic staff. Some of the universities depend on part-time and adjunct lecturers to make up for the deficiencies in the number of academic staff. A good number of the professors are fast approaching retirement age, but there are no comparable ready replacements for them. The younger lecturers appear not to show the level of 
commitment for older professors exhibited, consequently, the retirement of a professor leaves a big vacuum. On another dimension, the issue of quality of the available academic staff is not ade quately addressed, for thatreason, Wong \& Chiu (2020) emphasized that there is evidencethatsomelecturers in tertiary institutions ought not to be there by virtue of their academic background, low integrity, poor attitude to research and teaching, and discipline.

Asiabaka and Odionye (2011) observed that many of the best brains have consistently and gradually sort for and gained employment outside the country. Some highly trained academic staff who went for short courses, conferences and workshops outside the country used the opportunity to made necessary contacts that facilitated their securing employment in foreign countries. Thus, this study proffered solutions for a continuous and complete re-structuring of the human resource management model in our educational tertiary organizations today to reduce the risk linked with human capital developmentin the Nigerian educational tertiary institutions.

\section{RESEARCHMETHOD}

This study generates data from quantitative and qualitative sources, using questionnaire instrument to randomly collect a cross sectional data from the state owned polytechnic representing one of the two (2) existing polytechnics in Bauchi metropolis. A total of 45 structured questionnaires were administered on our respondents and 44 were valid for analysis. An in-depth face to face interview and Focus Group Discussion was carried out on 7 informants (Stakeholders and target beneficiaries) to corroborate the quantitativeresults. In line with the view of Creswell (2014) questionnairereturn rate is considered high and sufficient if it exceed 50 percent of the total dispatched to the field.

A structured questionnaire was developed and used in capturing respondents' perceptions on the positive roles of TETFund to human capital development. Descriptive statistical instruments in the form of frequency and percentage distributions were used in the initial data reduction stage, and then Chi square, $\mathrm{X}^{2}$, was computed to determine how significant the academic staffs' perceptions of human capital investment and it overall bearing on their work efficiency particularly in Bauchi state and the country in general. The researcher adopted the Chi-Square goodness-of-fit test to test the hypothesis. The Chi-Square statistics formula is given as: $\mathrm{X}^{2}=$ Summation of $(\mathrm{Oi}-\mathrm{Ei})^{2} / \mathrm{Ei}$, Where, $\mathrm{Oi}=$ Observed frequency and, $\mathrm{Ei}=$ Expected frequency. The degree of freedom $n=5, V=5-1=4$ and the level of significance $=5 \%$ or 0.05 . Note: $\mathrm{Ei}=$ Total frequency 45 divided by $5=9$

\section{RESULTS AND DISCUSSION}

\section{Conceptual framework of TETFund Academic-based intervention programmes}

In addition to strengthening, fostering and enhancing TEI's human and institutional capacities in teaching, study, entrepreneurship and growth of the Nigerian knowledge-based economy through successful implementation and delivery of interventions, the achievement of Nigeria's Vision 20:20:20 is essential to all TETFund Academic-based intervention programs. In other words, the department's academic intervention programs are designed to launch beneficiaries of TETFunds into world-class institutions with high-level capabilities to withstand and succeed in global competitiveness on the world market, effectively drive Nigeria's knowledge-based economy and continually engineer highly qualified manpower output (TETFund, 2015). 
Thus, through planning the human resources, management strives to have the right number and the right kinds of people, at the right places, at the right time, doing things, which result in both the organization and the individual receiving maximum long-run benefits (Bauchmüller et al., 2014). Obviously, the human resources planning in Nigeria faces the challenge of attractingand retaining the best possible academic staff. The polytechnic and university systems are in constant competition with the industrial and business community. Corporate bodies attract the young brilliant tpolytechnic or university graduates who would have gained employment in the polytechnics or universities as an instructor or graduate assistants respectively. This caliber of people, if employed, would have taken up post graduate studies and joined in the strengthening of the Nigerian polytechnic or universityeducation programmes.

\section{TETFund strategies for effective implementation of research \& development}

Since, there are rapid advances in information technology, science, corporate governance, transportation, agriculture, inventions, manufacturing and many more. We have been experiencing the jet age, a period of social and economic change brought by speed, fastness in transcontinental, intercontinental and global connectivity in knowledge, wisdom, learning, travels and human relation followed by the dynamisms of the current information age. A period characterized by the ability of individual to manage at the speed of change, to instantly access knowledge, skill, competencies and learning at any point in time for individual, corporate and national success. This has transformed to a digitalage, marked by multi-dimensional business information system following the invention of General Purpose Electronic Digital Computer in 1946, the Mathematical Framework Theory of Information in 1948, the World Wide Web (www) in 1989, the Digital Television in 1990 and the Digital Radio in 2004.

Recent Programme International Study Assessment (PISA) The Organization for Economic Cooperation and Development (OECD) analysis of 65 countries indicates a negative association between student education output in a country and total earnings (percentage of GDP) extracted from natural resources such as oil, gold, diamonds, etc. The study provides an insight into current problems: countries that are endowed with natural resources are jinxed with what has been called "Dutch Disease" or natural curses. This is because countries are almost trapped in the pitiful vortex of burgeoning natural resources, Never go into production or artistic technology. By institutionalizing and encouraging research and development, Nigeria will reverse all paradoxical development indicators (R \& D). Via collaborations with tertiary institutions, research centres, regulatory agencies and the private sector, TET Fund hasagreed to play its role in this respect.

This could be the beginning of a more prosperous future for this country if all main stakeholders join us, and it is only them that our higher education institutions can guarantee their survival in the world's ever evolving and highly competitive knowledge-driven economies (TETFund, 2015). 70\% of Research \& Development funds come from the manufacturing sector in most western countries. Just 0.2 percent in Nigeria comes from the manufacturing sector. Nothing clearly portrays the deficiency in driving R\&D in Nigeria as the lack of a national R\&D regulation and strengthening forum. The development of the R\&D Foundation was delayed. When a National R\&D Foundation isset up in Nigeria, the demand for concerted efforts can be easily accomplished. This will ensure that the national system for maintaining and implementing R\&D is organized. The National R\&D Foundation is responsible for supporting and enforcing legislative, rather than executive, R\&D policies. Such a foundation shall promote an effective interface between research centers or tertiary institutions, the government and the private sector, in particular the industrial sub-sector of the economy, when developed by law. Among other items, the 


\section{Khazanah Sosial, Vol. 3 No. 1 : 15 - 21}

Relationship between Human Capital Investment and Employees' Work Efficiency in ATAP Bauchi: The Relevance of TETFund Interventions

Hashim Sabo Bello, A'isha A.G. Umar, Muhammed Kabir Ibrahim

National R\&D Foundation should be charged with promoting, tracking and controlling the compulsory contribution of, say, $0.5 \%$ of the annual budget of all registered organizations (both profitand non -profit) for the purpose of R\&D, which must be established by law in order to channel, use and implement it for the shared benefit of researchers and the private sector (TETFund,2015).

\section{Findings}

The research adopted the descriptive statistics as well as the Chi-square, $\mathrm{X}^{2}$, to analyze the results and test the hypothesis to give the tentative prediction about the nature of the relationship between the research variables. The perceptions on the significant roles in hypothesis involve human capital investment and employees' work efficiency in educational polytechnic system. HYPOTHESIS: There is a significant relationship between TETFund intervention in human capital investment and employees' work efficiency within educational polytechnic system in Nigeria.

Table 1 just discloses the result of the respondents' perceptions of TETFund's human capital investment and employees' work efficiency in polytechnic system in the study area.

Table 1. Response on link between human capital investment \& employees' work efficiency

\begin{tabular}{ccc}
\hline Response & Frequency & Percentage \\
\hline Strongly Agree & 14 & 31.8 \\
Agree & 16 & 36.4 \\
Uncertain & 3 & 6.8 \\
Disagree & 6 & 13.6 \\
Strongly Disagree & 5 & 11.4 \\
\hline Total & $\mathbf{4 4}$ & $\mathbf{1 0 0}$ \\
\hline
\end{tabular}

Source: Field Survey (2017)

As deduced from the table above, 14 (31.8\%) and 16 (36.4\%) of the respondents strongly agreed and agreed respectively that the human capital investmentby TETFund have helped boost the employees' work efficiency in polytechnic system in the study area while $3(6.8 \%)$ and $6(13.6 \%)$ of the respondents strongly disagreed and disagreed respectively, whereas 5 (11.4\%) of the respondents were indifferent on the notion. The breakdown of the analysis shows that most respondents supported the hypothetical statement that "there is a significant relationship between TETFund interventions in human capital investment and employees' work efficiency within educational polytechnic system in Nigeria".

Accept the alternative hypothesis if the measured Chi-square value is greater than the Chi-square table value, but if not, reject the alternative and accept the null hypothesis seetable 2 .

Table 2 . the results of the questionnaire

\begin{tabular}{|c|c|c|c|c|}
\hline $\mathbf{0 i}$ & $\mathbf{E i}$ & Oi-Ei & $(\mathbf{O i}-\mathbf{E i})^{2}$ & $(\mathrm{Oi}-\mathrm{Ei}) 2 / \mathrm{Ei}$ \\
\hline 14 & 9 & 5 & 25 & 2.78 \\
\hline 16 & 9 & 7 & 49 & 5.44 \\
\hline 3 & 9 & (6) & 36 & 4.00 \\
\hline 6 & 9 & (3) & 9 & 1.00 \\
\hline 5 & 9 & (4) & 16 & 1.78 \\
\hline Total & & & & 15 \\
\hline
\end{tabular}

Source: Field Survey (2017)

\section{Discussion}

Since $\mathrm{X} 2$ is determined, the value 15 is lower than the value extracted from X2, i.e. 36.23 of the degree of freedom (n-1), we reject $\mathrm{H} 1$ (alternative) at the 5\% significance level and accept $\mathrm{H} 0$ (null 
Khazanah Sosial, Vol. 3 No. 1 : 15 - 21

Relationship between Human Capital Investment and Employees' Work Efficiency in ATAP Bauchi: The Relevance of TETFund Interventions

Hashim Sabo Bello, A'isha A.G. Umar, Muhammed Kabir Ibrahim

hypothesis). Via this test, it shows that the human capital investment of the TETFund have been effective in boosting the morale of staffs towards work efficiency within the educational polytechnic system in Nigeria. The result of this study is in congruent with the assertions proffered by the previous studies (Aluede et al., 2012; Gomez-Mejia et al., 2007; Hendry \& Pettigrew, 1990). Even though performance is often times It can also be calculated by the combination of predicted activity and task-related aspects, defined by financial figures. In fact, performance based on an absolute value or relative judgment may represent overall organizational performance. Tabiu \& Nura (2013) Employee work output has been graded into 'will-do' and 'can-do'. The former refers to the expertise, skills, abilities and other characteristics (KSAOs) of individuals needed to perform such work, and the latter denotes the level of motivation that individualsmight have to perform their work.

Human capital investment is a great way to improve the quality of human resources. The higher the human capital development the higher is the quality of the workforce in a workplace. This if all qualified workforce is actively involved in the workplace, there will increase the output of goods and services in an organization, which in turn drive economic growth. Economicgrowth, will create new investment, create jobs, and absorb the labour force, which in turn will make the population very productive. A highly qualified person who masters technology can generate added value and encourage economic growth, Seran (2019) found that $23 \%$ of US economic growth in the period of $1909-1929$, contributed by the increasing of the average education level of the workforce. The contribution was then increased to $42 \%$ in the period of 1929-1957. A similar study conducted by Schultz, in his book: Capital Formation by Education, he compared turnover rate between human capital and physical capital towards economic growth. From this comparison, Schultz (1964) found that a fairly high proportion of output growth in the USA caused by education investment in the development of human resources.

\section{CONCLUSION}

Since the affirmative purpose of human capital investment is to increase the degree of organizational success, consequently, this particular study have supported the assertion that organizations involved in human capital planning achieve better performance on the basis of various performance indicators than those that do not. Yes, this is true with organizational performances in tertiary educational institutions of Nigeria being that the results of this research study indicated that the TETFund intervention in training/development of the academic staffs of polytechnic exponentiallylead to their workefficiency in the polytechnicsystem. Therefore, training and development which translate into In several studies, work performance has become one of the important metrics for assessing organizational performance. As this research study examined the effects of TETFund intervention on human capital investments using polytechnic system instead of colleges of education and universities, then, this research study recommended for the public organizations in Nigeria especially the education institutions to harnessed and take full advantage of the reciprocal benefits of human capital investments and the work efficiency in educational tertiaryinstitutions as this willgo a long way to raise organizational achievement towards an end with the least amount of resources. The study also recommended for the human resources planning as it does enhance organizational performance Through the efficient and successful pursuit and achievement of goals. The protective function is to reduce risks by reducing business uncertainties and clarifying the implications of related management behavior. 


\section{Khazanah Sosial, Vol. 3 No. 1 : 15 - 21}

Relationship between Human Capital Investment and Employees' Work Efficiency in ATAP Bauchi: The Relevance of TETFund Interventions

Hashim Sabo Bello, A'isha A.G. Umar, Muhammed Kabir Ibrahim

\section{REFERENCES}

Adekola, A. I. (2014). Public investment in human capital and economic growth in Nigeria: analysis on regime shifts. Journal of Economics and Development Studies, 2(2), 213-231.

Adeyemi, P. A., \& Ogunsola, A. J. (2016). The impact of human capital development on economic growth in Nigeria: ARDL approach. IOSR Journal of Humanities and Social Science, 21(3), 17.

Aluede, O., Idogho, P. O., \& Imonikhe, J. S. (2012). Increasing access to university education in Nigeria: Present challenges and suggestions for the future. The African Symposium, 12(1), 3-13.

Anaduaka, U. S. (2014). Human capital development and economic growth: The Nigeria experience. International Journal of Academic Research in Business and Social Sciences, 4(4), 25.

Asiabaka, I.., \& Odionye, E. A. (2011). National Universities Commission (NUC) Minimum academic standard: Implication for quality teacher education programmes in Nigeria. Nigerian Journal of Professional Teachers., 1(6), 104-118.

Bauchmüller, R., Gørtz, M., \& Rasmussen, A. W. (2014). Long-run benefits from universal highquality preschooling. Early Childhood Research Quarterly, 29(4), 457-470.

Bello, H. S., Zachariah, R., \& Ibrahim, M. K. (2020). RELATIONSHIP BETWEEN HUMAN CAPITAL MANAGEMENT AND EMPLOYEES'VALUE ADDED IN SOME FEW SELECTED ORGANIZATIONS WITHIN BAUCHI METROPOLIS. Economics, Finance and Management Review, 3, 79-88.

Creswell, J. W. (2014). A concise introduction to mixed methods research. SAGE publications.

Gomez-Mejia, L. R., Balkin, D. B., Cardy, R. L., \& Carson, K. P. (2007). Managing human resources. Pearson/Prentice Hall Upper Saddle River, NJ.

Hendry, C., \& Pettigrew, A. (1990). Human resource management: an agenda for the 1990s. International Journal of Human Resource Management, 1(1), 17-43.

Khalid, P. S. M., \& Anuar, H. S. (2020). Internal Service Quality in IT Service Management: IT Services Professionals' Perspectives.

Samwel, J. O. (2018). Human Resource Planning as an Important Practice to Anticipate Future Human Resource Requirements of the Organization-Literature review. International Journal of Research in Business Studies and Management, 5(3), 24-30.

Schultz, T. . (1964). Capital Formation by Education. Journal of Political Economy. www.http//.uvm.edu/

Seran, S. (2019). Social Economic Status to the Number of Life Expectancy. International Journal of Economics and Financial Issues, 9(4), 166.

Tabiu, A., \& Nura, A. A. (2013). Assessing the effects of human resource management (HRM) practices on employee job performance: A study of usmanu danfodiyo university sokoto. Journal of Business Studies Quarterly, 5(2), 247.

TETFund. (2011). Tertiary Education Trust Fund (Establishment, etc) Act No. 16 of 2011: Federal Republic of Nigeria Official Gazette.

TETFund. (2015). TETFund's Positive Change in Tertiary Institutions: A Compendium of TETFund Interventions.

Wong, B., \& Chiu, Y.-L. T. (2020). University lecturers' construction of the 'ideal'undergraduate student. Journal of Further and Higher Education, 44(1), 54-68. 